Kovalets, I.V., Maistrenko, S.Ya., Khalchenkov, A.V., Zagreba, T.A., Khurtsilava, K.V., Anulich, S.N., Bespalov, V.P., and Udovenko, O.I.

Institute for Mathematical Machines and Systems Problems, the NAS of Ukraine, 42, Glushkov Ave., Kyiv, 03187, Ukraine

tel. +380 44526 3615, ivkov084@gmail.com

\title{
POVITRYA WEB-BASED SOFTWARE SYSTEM FOR OPERATIONAL FORECASTING ATMOSPHERIC POLLUTION AFTER MANMADE ACCIDENTS IN UKRAINE
}

\begin{abstract}
Within the framework of this research, information technology for forecasting atmospheric pollutant transport following manmade accidents with emissions of hazardous matters has been developed. It is based on the integration of emission scenarios, atmospheric transport models of different complexity (from simplified local screening models to CALPUFF regional model), weather forecasting tools. Using freeware GIS-and Web-technologies a pilot version of Povitrya webbased software and simulation system for analysis and forecast of air pollution in Ukraine caused by manmade disasters has been created and applied to simulation of air pollution following fire at oil storage facility in Vasylkiv, in June 2015.
\end{abstract}

Keywords: air pollution, web-system, GIS, numerical weather prediction, accident, atmospheric dispersion, Vasylkiv, fire, and oil storage facility.

\section{INTRODUCTION}

In Ukraine, there are no operational systems that enable forecast and assessment of consequences of large amount of airborne releases into the atmosphere following heavy manmade accidents. Applicability of the existing and officially approved methodologies by the State Emergency Service of Ukraine (SESU) and by the Ministry of Defense of Ukraine [1, 2] is, first of all, limited to short duration releases, when constant meteorological conditions could be assumed. Secondly, even those simplified methodologies have not been implemented in software products for SESU experts responsible for emergency response. The exception is the EU nuclear emergency response system RODOS (https://resy5.iket.kit.edu) that

(C) KOVALETS, I.V., MAISTRENKO, S.Ya., KHALCHENKOV, A.V., ZAGREBA, T.A., KHURTSILAVA, K.V., ANULICH, S.N.,

BESPALOV, V.P., and UDOVENKO, O.I., 2017 has been recently implemented in Ukraine with EU support for emergency response in the case of nuclear emergencies at the Ukrainian nuclear power plants [3]. To assess air pollution following release of non-radioactive airborne pollutants, systems similar to RODOS have been developed in the world. The widely known examples are ARGOS [4] and NARAC (https://narac.llnl.gov) systems. However, firstly, these systems are not freely available and, secondly, they are mostly desktop applications (similar to RODOS). This complicates access to such system for a wide range of experts which could be interested in performing calculations in the case of emergency. The web-based systems for operational forecast of chemical dispersion following accidents have been recently developed in some research, e. g. [5]. However, it is reasonable to develop in Ukraine a national system comprising contemporary models together with those officially appro- 
ved in Ukraine, which utilizes numerical weather prediction (NWP) data covering Ukraine. Therefore, the goal of present research is to develop a web-based system (hereafter referred to as Povitrya system) for forecasting airborne pollution and consequences of manmade accidents, which is based exclusively on free software tools (GIS, database, models) and which implements the simplified (screening) models officially approved in Ukraine, on the one hand, and the contemporary atmospheric dispersion models which perform calculations using numerical weather prediction (NWP) data, on the other hand. This research continues the previous work [6] in Povitrya system has been partly developed based on screening models.

\section{THE SYSTEM PRESENTATION \\ The architecture overview and the development of Povitrya system environment}

The primary task of the Povitrya system is to forecast zones of dangerous concentrations after accidental releases of hazardous matters in atmosphere. Since in Ukraine, there have been officially approved screening models for the assessment of affected regions following accidental air pollution [1, 2], they are integrated in the Povitrya system as option for quick assessment of the affected regions. However, if the release has a long duration ( $>1$ hour) and if the distance to maximum concentrations are likely to exceed $10-20 \mathrm{~km}$, the use of these officially approved screening models may lead to unrealistic results. Therefore, the second option is to calculate regional scale atmospheric dispersion using CALPUFF model and data of numerical weather prediction system operating in Ukrainian Hydrometeorological Center (UHMC).

The Poritrya system is based on WEB-technologies. Schematically, the system architecture is showed in Fig. 1. The system is developed using free software. The following programming languages were used to develop the system: JavaScript [7] - to create a user interface and to use the AJAX-approach to building Web applications and PHP [8] - to establish communication between the Web-server and the database. As DBMS, PostgreSQL is chosen, which is a free object-relational database management system. PostGIS adds additional functionality to the PostgreSQL database. In particular, it expands the capabilities of PostgreSQL in terms of storing spatial data, querying and managing them.

To visualize the results of calculations and to obtain additional information, a geoinformation component is created in the system. It uses OpenStreetMap as base map data [9], which is an open project for creating public maps of the world. Using OpenStreetMap enables to have actual maps and to effectively display relevant information on the WEB-client due to the tile approach.

However, OpenStreetMap data are not sufficient to perform additional analysis, such as, for example, calculating the time of arrival of hazardous chemical substances, the affected area and the population losses from the precipitations fallen into the affected areas, as well as other indicators that require spatial information. For such

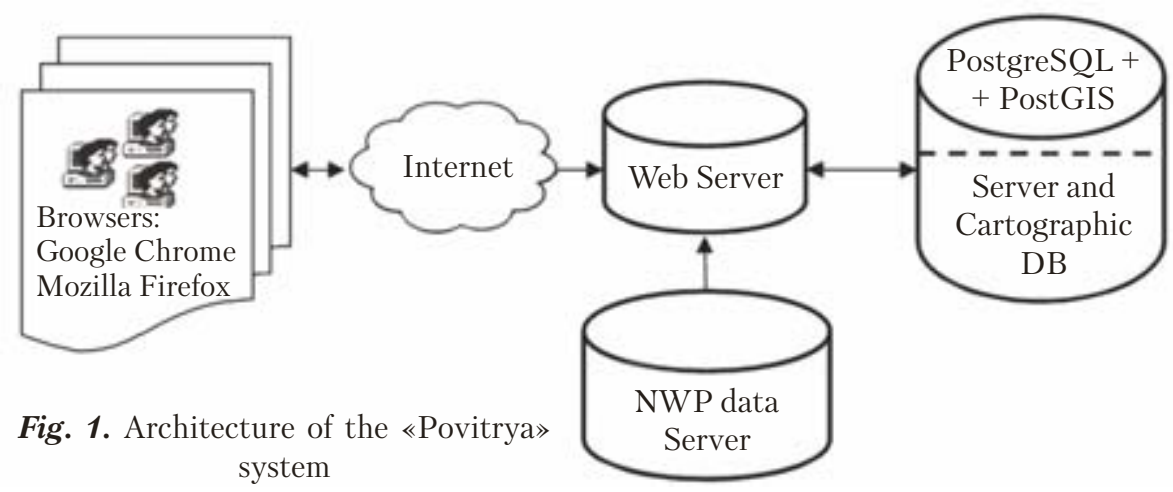


calculations, polygonal layers of regions, districts, settlements with information on the number of population and forest areas of the territory for which forecast is performed are required. The polygonal layer of settlements in OpenStreetMap contains information only for about 13000 administrative units and only for some of them the number of population is indicated. For the time being, in Ukraine, there are over 30,000 localities. Therefore, to solve this problem, the Povitrya system uses corresponding thematic layers of the map of Ukraine at a scale of $1: 200000$ in the geographic coordinate system GCS_Pulkovo_1942. Since, in the OpenStreetMap, the World Geodetic System 1984 (WGS-84) is for joint use, additional thematic layers have been translated into WGS-84 coordinate systems. The transformation was made by 7 parametric transformations. For the system, additional thematic layers using the PostGIS application are placed in the PostgreSQL mapping database. PostGIS enables efficient spatial queries to the database, even for a fairly large amount of spatial data.

JavaScript library Leaflet and Turf library are used for mapping the geometric objects created on the basis of calculated data such as projected zone of chemical contamination, zone of possible chemical contamination, the accident zone, the contamination zones of the primary and secondary clouds of hazardous substances etc., and for performing additional geometric operations such as geometric cross-section, respectively.

\section{Simulation subsystem based on screening models}

This part of the Povitrya system is based on implementation of screening models approved by the Ministry of Emergency of Ukraine [1] (hereafter referred to as «the ME methodology») and screening model [2] approved by the Ministry of Defense of Ukraine (hereafter referred to as «the MD methodology»). These methodologies have some differences regarding the type of forecast, input information and basic tabular data required for the calculations and initial set of results ob-

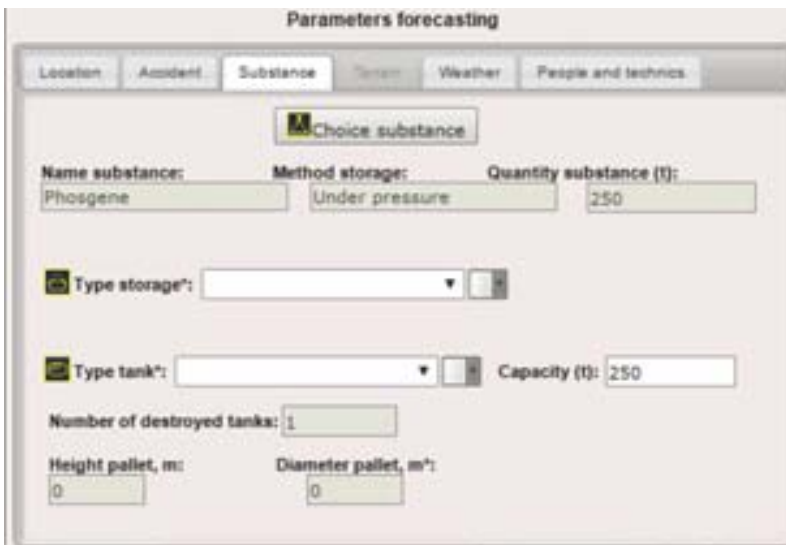

Putting data on substance

Substance

- Substances with known PCP:

Substances entered by the User:

Other (specify PCP):

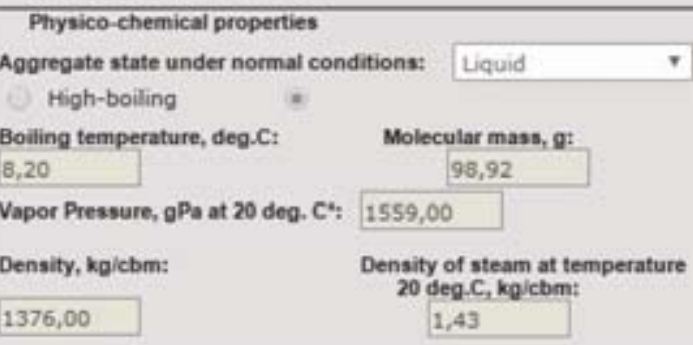

Specific caloric of evaporation $\mathrm{kJ} / \mathrm{kg}$

At temper. 20deg.C: 231,60 At temper. bolling: 239,40

Specific heat, k.Jkg*deg

At temper. 20deg.C: 1,35 At temper, boiling: 1,01

Toxicity (toxicdose), $\sigma^{*}=/ c^{\prime}$

Threshold: 13,00 Average: 0,00 Lethar: 0,00

Ut 3 ave data on substance

Storage substance

Mictricne cumocti:

250

Fadd to total quantity

Total quantity

substance (t):

250

Method storage: Under pressure

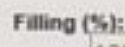

100

Clear data tanks

Total number

tanks:

1

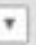

Fig. 2. Input windows of the Povitrya system for setting release scenario for screening models 
tained. The high-level selection option is «type of prediction». Depending on this parameter, either «emergency» or «long-term forecast» type of calculation is performed. For the «emergency» calculation, methodology [1] or [2] is selected. For the methodology [2], two types of calculations are provided: the tabular, the method-based tables, and the analytical one based on analytical formulas. In the «long-term forecast» mode, the calculations are carried out in advance to determine the possible accident consequences.

The «type of hazardous substance» defines substance considered. The methodology [1] enables carrying out calculations for 28 chemically hazardous substances, including basic chlorine, ammonia, sulfur dioxide, hydrogen sulfide, carbon disulfide, hydrochloric acid, chloropicrin, formaldehyde, and twenty additional substances. The methodology [2] is designed to perform calculations for eighteen substances. For the most widely considered substances such as chlorine, ammonia, sulfur dioxide and others, both methodologies can be used. In addition, the analytical form of calculations based on the methodology [2] allows the user to make a prediction for chemically hazardous substances that are not available in the list if the necessary physicochemical properties of the corresponding substance are known.

The amount of substance in the affected area is also set by the user. For the methodology [1] the maximum amount of hazardous substances in tanks is up to 300 tons, while for the methodology [2] this indicator is determined by specific type of substance.

The calculated results for both methodologies are similar in general, but differ in details. The methodology [1] uses the following parameters: the cloud spreading depth (the affected area), the zone of possible chemical contamination, the area and width of the projected zone, the evaporation time and the time of hazardous cloud arrival, the forecasted contaminated area and population loss, the degree of chemical danger to administrative-territorial units involved in the affected area.
The methodology [2] outputs are the radius of accident zone, the depth of propagation and the area of contamination zone separately for the primary and secondary clouds, the evaporation time of released matter, the duration of chemical contamination, the cloud arrival time, and the forecasted human losses in the affected area. In addition, for the primary and secondary clouds, four zones of damage are distinguished: the deadly, the medium, the light, and the threshold.

The Povitrya system visualizes the results of calculations on the map and provides a report for each type of forecast. Using standard means of WEB-browser generated reports, the user can print and save the results on the WEB-client. All calculations are stored in the system, both for further viewing and for performing repeated calculations based on preliminary data with the possibility of changing the required parameters. This function is aimed at reducing the user's repeated actions when preparing data for forecast.

To make forecasts the user needs to select the desired view of the system's main menu and to set the forecast parameters. The user can set all the necessary parameters for the first time («to create new» mode) or use the parameters of previous forecasts (the «log» mode) and make required changes. It is necessary to indicate brief information about the accident and the substances (date and time of accident, pressurized or non-pressurized storage, quantity of substance in the vessel, height and diameter of pallet, and other according to Fig. 2). Information on weather conditions (wind speed and direction, stability category), topography and vegetation types shall be specified as well. If the calculation is successful, the key calculation data will be displayed.

\section{Forecast subsystem based on regional-scale atmospheric dispersion models and numerical weather forecast}

In the case of long lasting releases and dispersion beyond $10-20 \mathrm{~km}$ it may be important to account for temporal variations in meteorological data and dispersion conditions. Realistic disper- 


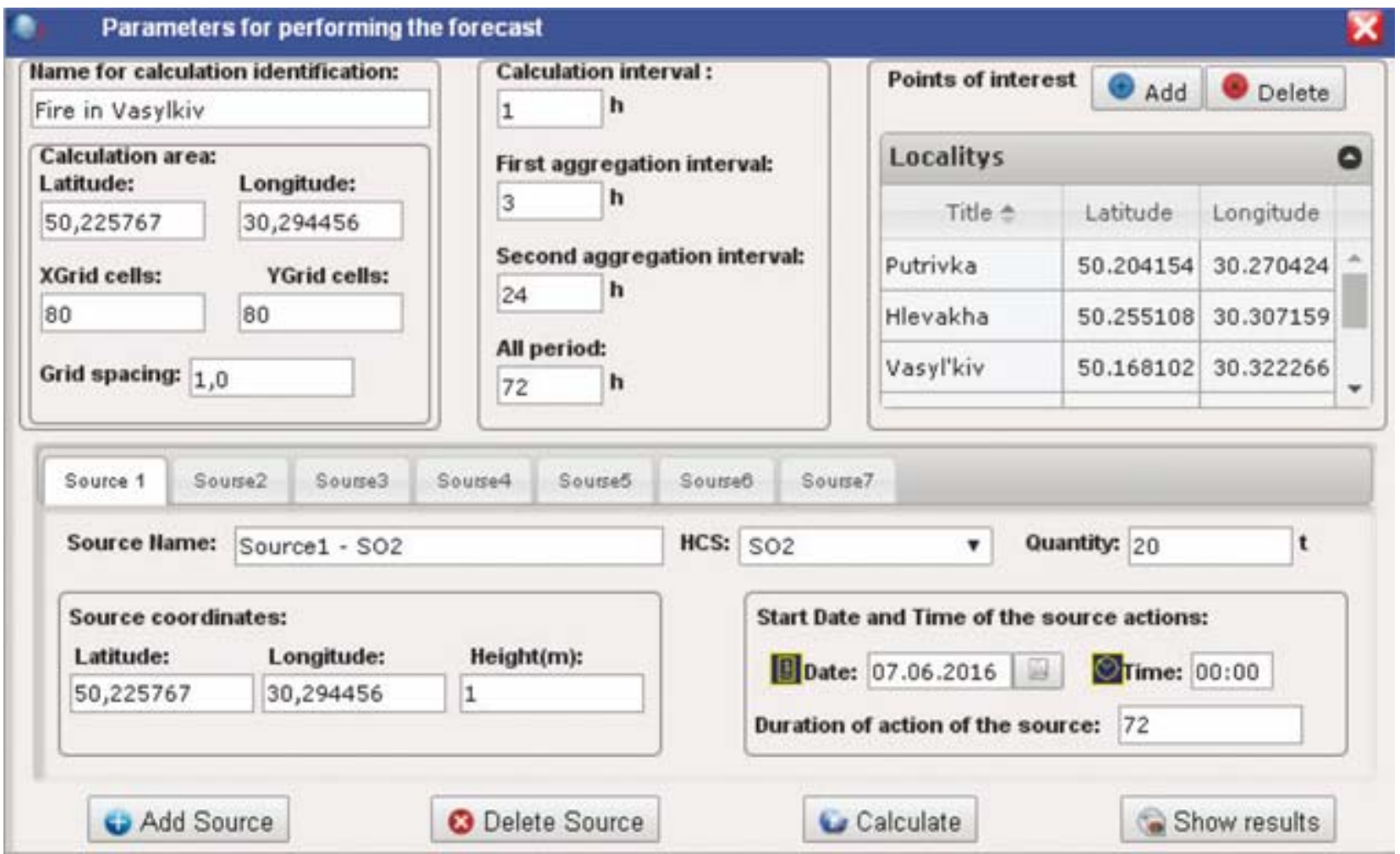

Fig. 3. Input window of the Povitrya system for entering source term parameters for the CALPUFF model

sion patterns could be obtained by application of the contemporary atmospheric transport models such as CALPUFF/CALMET model chain [10] and using data of numerical weather forecast systems. Within the framework of ongoing project on implementation of the EU RODOS nuclear emergency response system in Ukraine the numerical weather forecast system WRF-Ukraine based on freely available WRF mesoscale meteorological model (http://wrf-model.org/) has been installed at Ukrainian Hydrometeorological Center. WRF-Ukraine calculates numerical weather forecast data necessary for operating the RODOS system [11, 12]. The example of WRF-Ukraine operates also in the premises of IMMSP. The Povitrya system is connected to both WRF-Ukraine systems obtaining all necessary information for calculating meteorological data based on them.

The regional atmospheric dispersion model CALPUFF is used in Povitrya system as recom- mended by the US Environmental Protection Agency for applications at regional scales (from $50 \mathrm{~km}$ to $1000 \mathrm{~km}$ ). In practice, CALPUFF frequently applies to distances down to $100 \mathrm{~m}$ [13] and was previously used in Ukraine in environment assessment studies [13]. The model is capable of taking into account the influence on atmospheric dispersion of dry and wet deposition, chemical reactions, transient and inhomogeneous meteorological conditions and complicated topography. The output fields calculated by the model are gridded fields of air pollutant instantaneous concentrations further processed to obtain maximum/minimum and average concentrations.

CALMET diagnostic meteorological model is for ensuring the interaction of the CALPUFF atmospheric dispersion model and the numerical weather prediction model. In the Povitrya system, CALMET reads prognostic meteorological 
data calculated by WRF using the CALWRF utility and prepares input data for the CALPUFF model. The full list of meteorological fields transferred from WRF to CALMET includes timedependent two- and three-dimensional fields. Two-dimensional fields transferred to CALMET are the fields of sea level pressure, hourly precipitation rate, snow mask, shortwave and longwave radiation, $2 \mathrm{~m}$ temperature and relative humidity, skin surface temperature, $10 \mathrm{~m}$ wind direction and speed. Three-dimensional fields include: pressure and height above sea level, wind speed and direction, vertical velocity, temperature and humidity, water vapor, cloud, ice, graupel and snow mixing ratios. After preparation of the input data, CALMET calculates different meteorological variables required by CALPUFF on fine grid with taking into account empirical parameterizations and influence of topography on the wind field. In addition to the standard meteorological variables mentioned above, CALPUFF calculates such fields as planetary boundary layer height, stability categories, Monin-Obukhov length and others necessary parameters for CALPUFF.

Setting of the source term for the CALPUFF model in the Povitrya system requires specification of emitted substance, emission rate, emission start and end time, and emission coordinates (Fig. 3). The system supports calculation of atmospheric dispersion from multiple sources. That feature of the system could be used also to simulate vertically and/or time distributed emissions

\section{Calculation of affected territories by screening models}

For demonstration of the system's capabilities we choose the hypothetical scenario of chlorine release described in [14] in which 67.5 ton chlorine was emitted during 5 minutes under stable meteorological conditions (stability category F) with light wind $(3 \mathrm{~m} / \mathrm{s})$. Several contemporary dispersion models were evaluated in [14] against this scenario. According to Fig. 6, from the research [14], chlorine maximum permissible levels $(20 \mathrm{ppm})$ were simulated at distances from $\approx 7$ to $\approx 30 \mathrm{~km}$. Therefore, travel time of cloud to such distances was from 8 to 30 times larger than the emission duration. Even though screening models of the Povitrya system does not allow for setting exactly the same scenario, since, as described above, the emission duration was short as compared with the travel time at which significant levels of chlorine were expected this emission is simulated as leakage from vessel containing 68 ton chlorine, without any pallet.

The simulated results with the ME sub-model is showed in Fig. 4. The distance to maximum permissible concentration is $27 \mathrm{~km}$ which falls within range of distances reported for the same concentrations in [14], but close to the upper limit of that range $(7-30 \mathrm{~km})$. As expected, the screening models in Povitrya system give more conservative results as compared with other models.

Together with estimation of affected areas the system enables also assessing consequences of such emission in terms of affected population (Fig. 5) calculated based on GIS processing of the calculated results using the geospatial data on settlements and population available in the system. For each settlement within contaminated zone, the system enables to estimate the affected population, time of plume arrival, and danger level (Fig. 6).

\section{Simulation of air pollution following the fire at the oil storage facility in Vasylkiv}

The fire at oil storage facility in Vasylkiv, Kyiv Oblast (June 8-16, 2015) is an example of large manmade catastrophe which led to long lasting emission of pollutants into atmosphere. The active fire lasted 6 days with release of large amounts of $\mathrm{SO}_{2}$ and $\mathrm{NO}_{2}$ dispersed around thereby creating dangerous conditions for the population. The long lasting release led to the necessity of taking into account the spatial and time variations of meteorological conditions, which in the prognostic mode could be done only using numerical weather forecast systems. Therefore, the meteorological fields were simulated using WRF-Uk- 


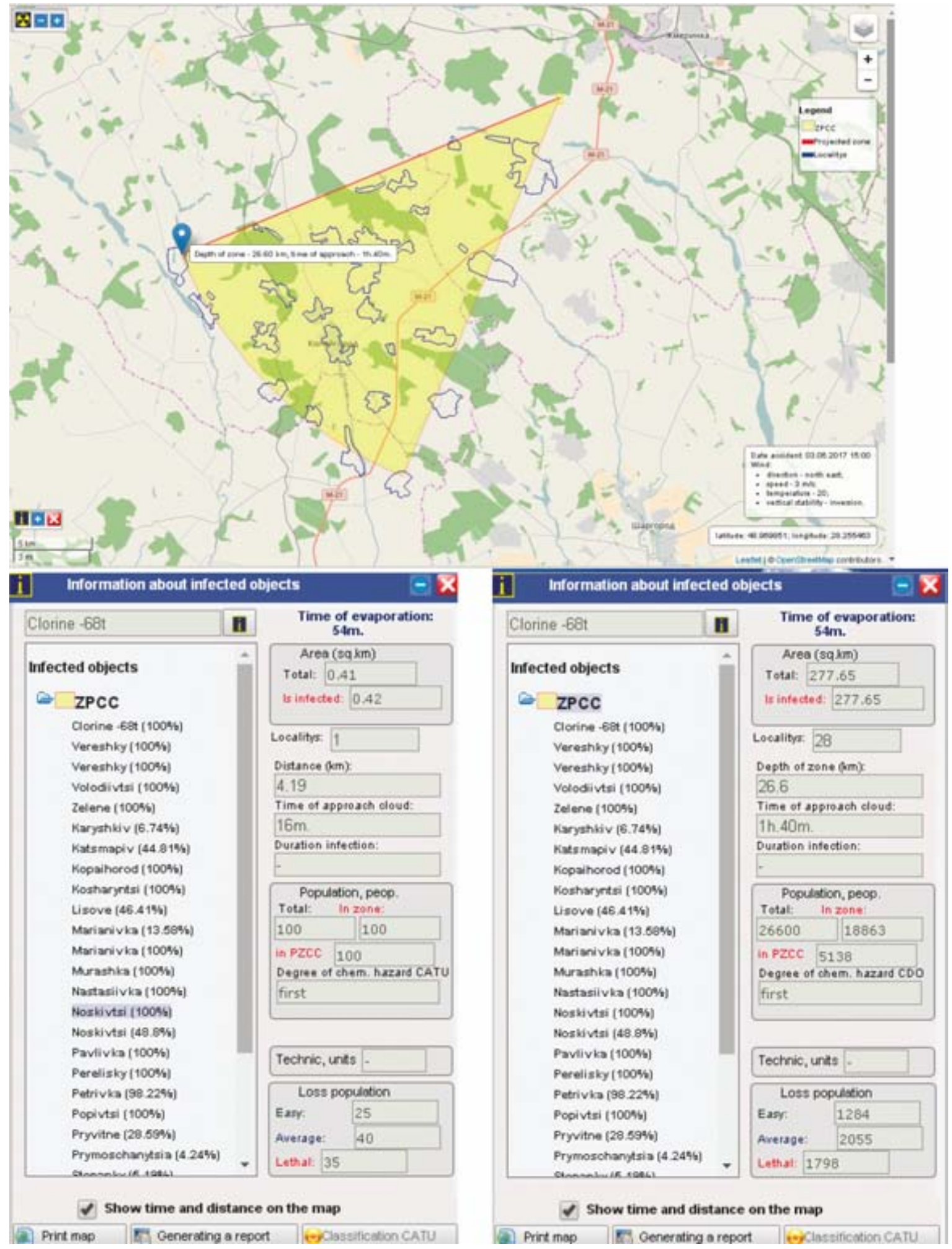

Fig. 4. Results of the screening ME model operated in Povitrya system for the scenario of release of chlorine described in text. Upper - affected zone; bottom left - summary of the affected areas and popolution loss; bottom right - summary of plume arrival time and population loss for selected settlement (Noskivtsi) 


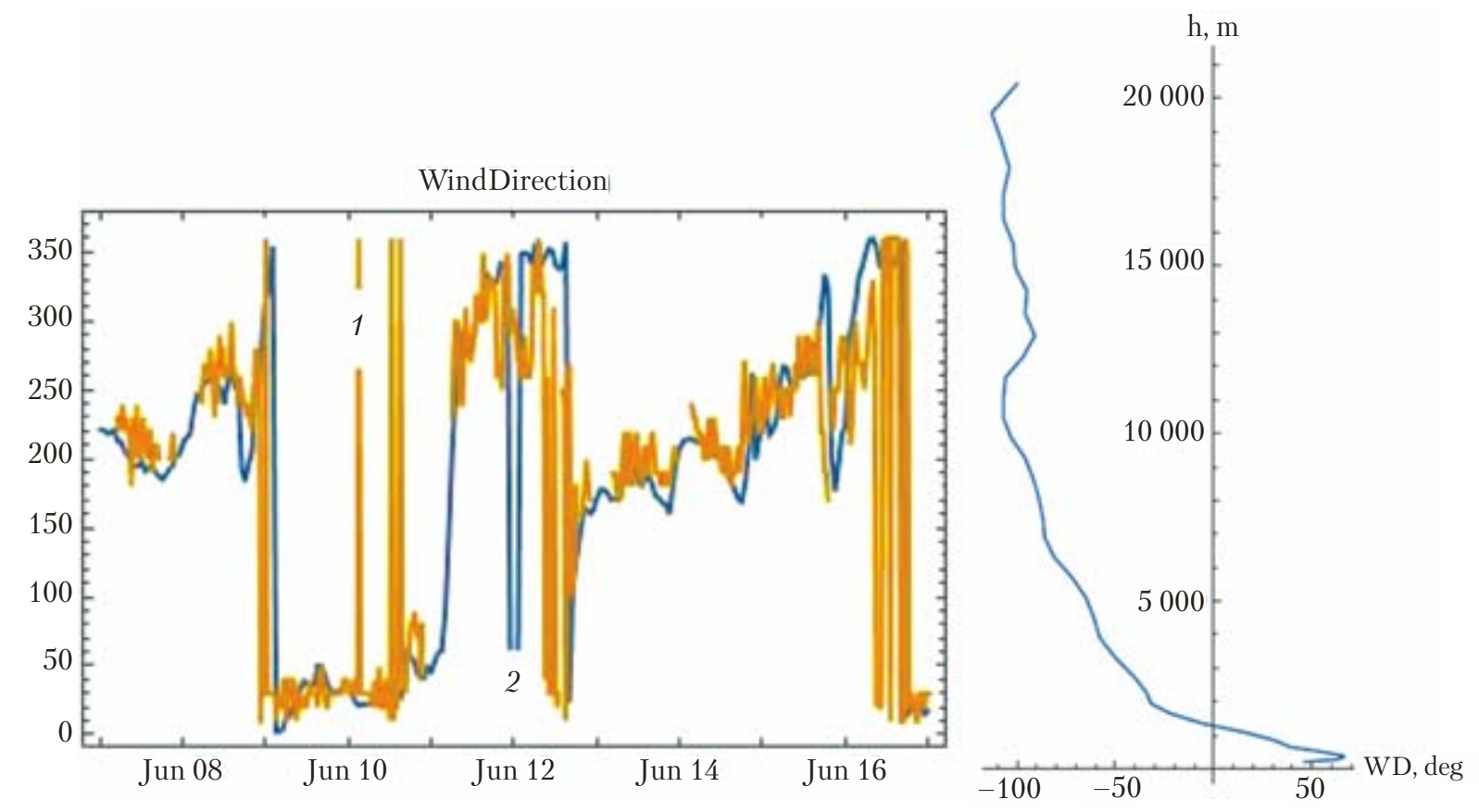

Fig. 5. Measured (1) and calculated with WRF-Ukraine (2) wind directions at airport Zhuliany for the period of fire in Vasylkiv (left); Vertical variation of wind direction with height calculated with WRF-Ukraine at the same place for 11 June 2015, 00h

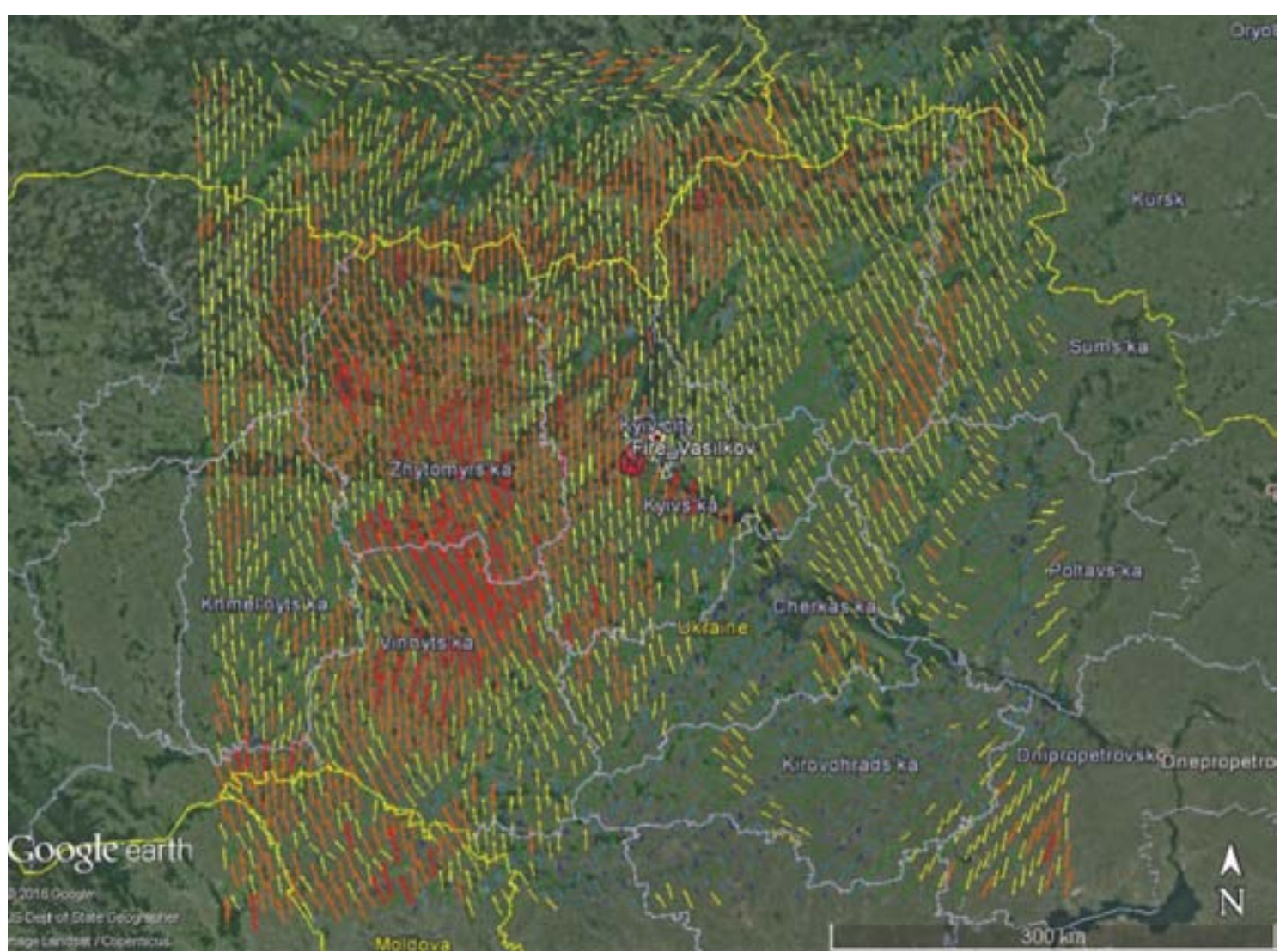

Fig. 6. Calculated with WRF-Ukraine wind field near surface averaged for 13 June 2015 


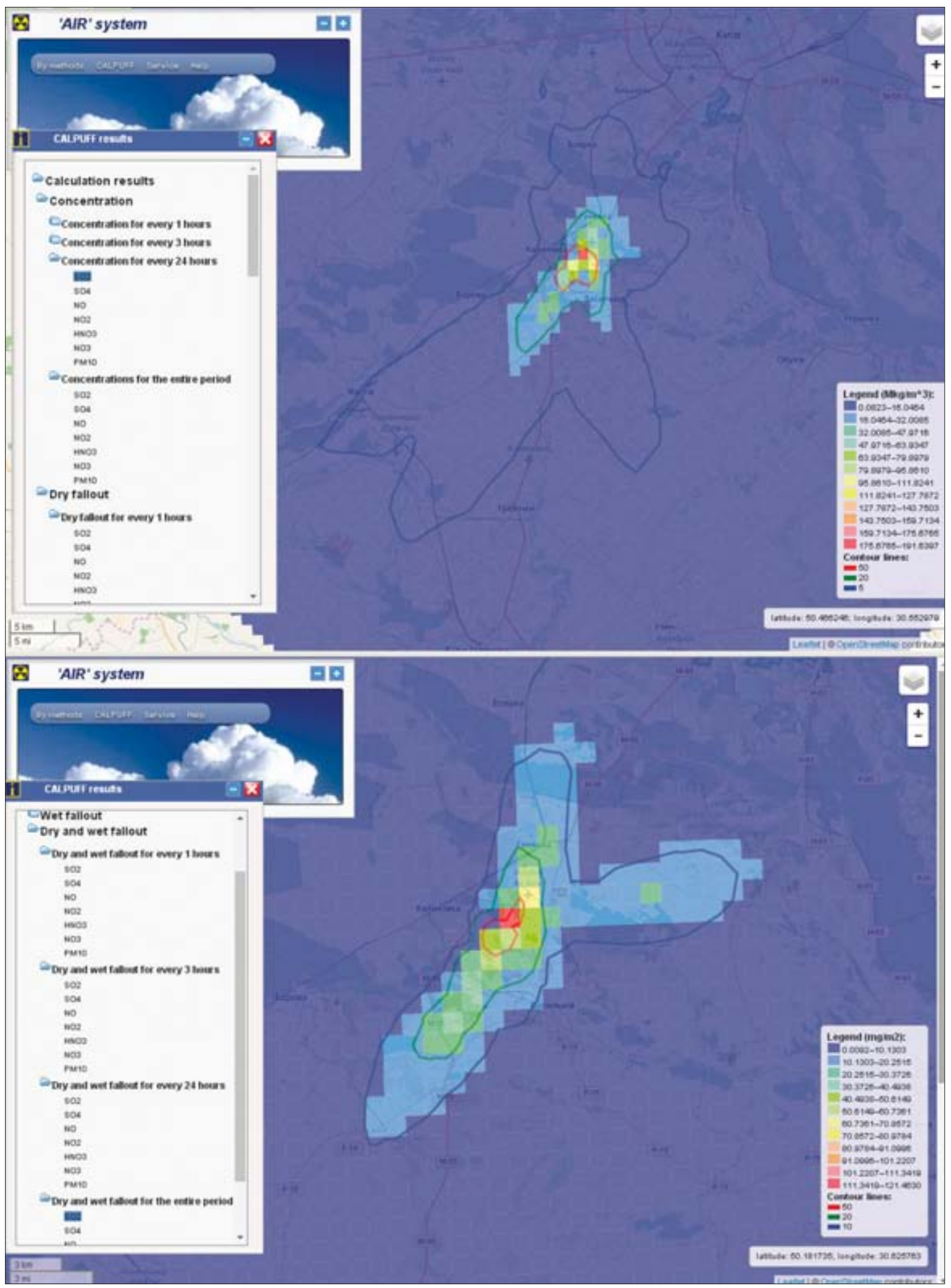

Fig. 7. Calculated maximum daily concentrations of $\mathrm{SO}_{2}$ in air (upper, ug $/ \mathrm{m}^{3}$ ) and total deposition of $\mathrm{SO}_{2}$ (bottom, $\mathrm{mg} / \mathrm{m}^{2}$ ) for the period of fire in Vasylkiv 


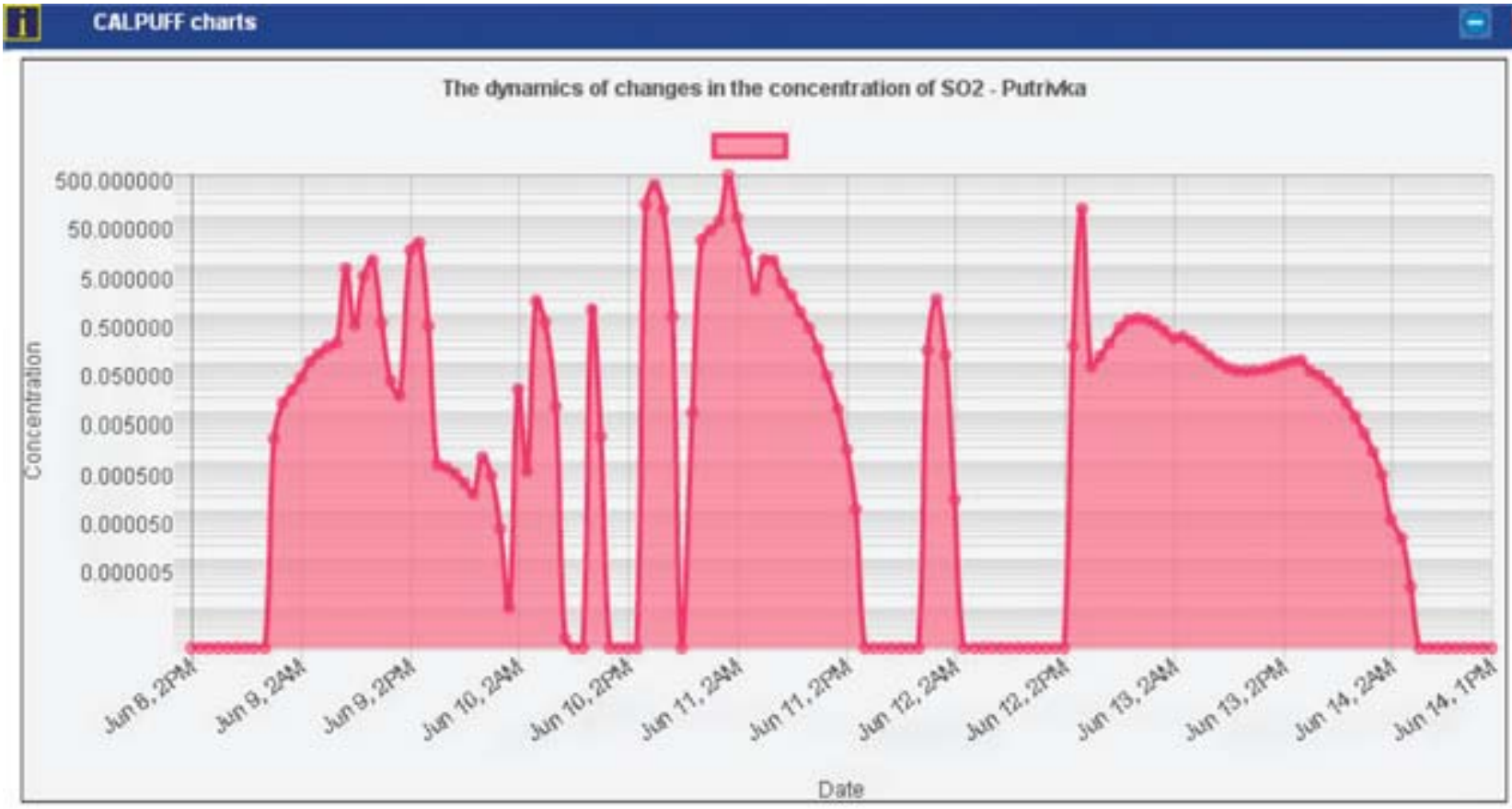

Fig. 8. Time series of calculated concentrations of $\mathrm{SO}_{2}$ in air $\left(\mathrm{ug} / \mathrm{m}^{3}\right)$ visualized by Povitrya system

raine meteorological forecast system mentioned above with specially introduced inner computational domain of $600 \times 600 \mathrm{~km}$ with $3 \mathrm{~km}$ resolution centered at the place of fire. The initial and boundary conditions were taken from the US NCEP Final Analysis global meteorological data available at the NOMADS servers (http://nomads.ncep.noaa.gov). Fig. 5 presents the simulated time variation of $10 \mathrm{~m}$ wind direction at the closest meteorological station located at the Zhuliany Airport together with corresponding measurements which agree well with the calculated results. The same Figure shows the simulated vertical distribution of wind direction for June 11, 2015, 00, while Fig. 6 features the spatial inhomogeneity of wind field: hence, it is important to take into account both vertical and horizontal variations of wind direction in simulations, especially, when the emission is vertically distributed as in the present case.

The active fire lasted 6 days with about 14,000 tons of oil products burnt [15]. Assuming a uniform combustion rate, we obtain a value of
$27 \mathrm{~kg} / \mathrm{s}$. The emission factors for two main pollutants, $\mathrm{SO}_{2}$ and $\mathrm{NO}_{2}$, were conservatively estimated at $0.03 \mathrm{~kg} / \mathrm{kg}$. This is a round-off of the corresponding figures obtained for diesel fuel according to [16]. Therefore, both pollutants were emitted with a rate of $0.81 \mathrm{~kg} / \mathrm{s}$. The vertical distribution of pollution source was simulated by 100 point sources distributed in a layer from 0 to $1000 \mathrm{~m}$ above ground and having a uniform emission rate distribution.

The pollution was simulated for the period from 2015.06.08, 14:00 to 2015.06.14, 14:00. The RIVAD/ARM3 chemical mechanism was used in CALPUFF simulations [10], with six pollutants simulated: $\mathrm{SO}_{2} \mathrm{NO}_{2}, \mathrm{SO}_{4}, \mathrm{NO}_{3}, \mathrm{HNO}_{3}$. The last three pollutants were formed from $\mathrm{SO}_{2}$ and $\mathrm{NO}_{2}$ as a result of reactions. Dry and wet depositions were taken into account according to available CALPUFF parameterizations. Dispersion coefficients were determined using the Pasquill-Gifford scheme for the rural conditions and the McElroy-Pooler scheme for the urban conditions [10]. 
Fig. 7 shows the calculated maximum daily $\mathrm{SO}_{2}$ concentration in air and total deposition of the same chemical during the accident. A complex pattern of air pollution and deposition due to variable meteorological conditions has been demonstrated. High $\mathrm{SO}_{2}$ concentrations of $5 \mathrm{mg} / \mathrm{m}^{3}$ could be reached up to $40 \mathrm{~km}$ distance from the place of fire. Time series of simulated $\mathrm{SO}_{2}$ concentrations in air at Putrivka is also featured in Fig. 8. According to simulations, this settlement is characterized by maximum simulated $\mathrm{SO}_{2}$ concentration. However, according to statistical analysis of simulated results, frequency of excess of $20 \mathrm{ug} / \mathrm{m}^{3}$ threshold concentration in Putrivka was $6.9 \%$, while in Vasylkiv and Glevakha it was higher (13.8\% and $11.8 \%$, respectively).

\section{Conclusions}

This research has resulted in creating an information technology for forecasting atmospheric transport of pollutants following accidents with emissions of hazardous matters. It is based on the integration of emission scenarios, atmospheric transport models of different complexities (from the highly simplified screening models to the CALPUFF contemporary model), weather forecast tools, GIS and Web-based technologies. A pilot version of Povitrya web-based software and simulation system for analysis and forecast of air pollution in Ukraine as a result of manmade disasters has been created with only freely available software tools (GIS, database, models) used. The Povitrya system consists of two subsystems: the first subsystem is based on highly simplified screening models officially recommended in Ukraine. In the case of regional-scale dispersion problems and long lasting emissions the second subsystem has been developed with CALPUFF atmospheric dispersion model integrated within the system. It operates using the data of WRFUkraine numerical weather forecast system. A simplified version of the Povitrya system (subsystem based on screening models) has been configured and installed at the Ukrainian Research Institute for Civil Protection of the State Emergency
Service of Ukraine. It is also available through Internet (http://env.kiev.ua:88).

The system functional capabilities have been demonstrated by simulating a hypothetical dispersion scenario of chlorine release published in literature for which the screening models of the Povitrya system produced results comparable to the other published models. The system capabilities have been also showed by simulation of air pollution after the fire at the oil storage facility in Vasylkiv, in June 2015. The calculated air pollution and deposition pattern was complex due to spatial and time variability of meteorological fields which can be taken into account only using contemporary dispersion models combined with NWP data. According to simulation results, the calculated concentrations of sulfur dioxide during the fire reached $5 \mathrm{ug} / \mathrm{m}^{3}$, at a distance up to $40 \mathrm{~km}$ from the fire.

To conclude, the Povitrya system implementation in Ukraine will increase efficiency of emergency response in case of manmade disasters.

The present work has been supported by Innovation project of the NAS of Ukraine (2016) and with the Grant of the President of Ukraine for doctors of sciences $\Phi 74 / 24981$.

\section{REFERENCES}

1. Ministry of Emergencies of Ukraine. Method of forecasting of consequences of releases of toxic substances following accidents at industrial facilities and transport. Registered in Ministry of Justice of Ukraine 10 April 2001 за N326/5517. URL: http://zakon3.rada.gov.ua/ laws/show/z0326-01 (Last accessed: 05.05.17).

2. Ministry of Defense of USSR. Method of assessment of chemical situation following accidents at facilities containing toxic substances. Moskva, 1989 [in Ukrainian].

3. Zheleznyak M.I., Kovalets I.V., Raskob W., Ievdin I. (2016) Project of adaptation of the JRODOS system for the Chernobyl Exclusion Zone. Proc. of the $1^{\text {st }}$ Int. Conf. on «Nuclear Decommissioning and Environment Recovery» INUDECO 2016 (Slavutich, Ukraine, 25-27 April 2016 ). P. 48-56 [in Ukrainian].

4. Hoe S., Schou-Jensen L., Pehrsson J. [et al.]. ARGOS CBRN information system for emergency management. Version 08. Denmark, Brondby: Prolog Developer Center, 2010.33 p. URL: www.pdc.dk/argos/ (Last accessed: 05.05.17). 
5. Kukkonen J., Nikmo J., Riikonen K. An improved version of the consequence analysis model for chemical emergencies, ESCAPE. Atmospheric Environment, 2017. 150: 198-209.

6. Maystrenko S.Y., Kovalets I.V., Bespalov V.P., Zagreba T.O., Khurtsilava K.V. Prototype version of the «Air» system to calculate the affected areas as a result of hazardous emissions into the atmosphere through the use of screening models and Web-based technologies. Matematichni mashini ta sistemi (Mathematical Machines and Systems) 2016. 4: 33-41 [in Ukrainian].

7. JavaScript. URL: https://uk.wikipedia.org/wiki/ JavaScript (Last accessed: 05.05.17).

8. PHP. URL: https://uk.wikipedia.org/wiki/PHP (Last accessed: 05.05.17).

9. OpenStreetMap URL: https://uk.wikipedia.org/wiki/ OpenStreetMap (Last accessed: 05.05.17).

10. Scire J.S., Strimaitis D.G., Yamartino R.J. (1998) A user's guide for the CALPUFF dispersion model (Version 5), 1998, Earth Tech. Inc., Concord, MA. URL: http://www. src.com/calpuff/calpuff1.htm (Last accessed: 05.05.17).

11. Didkivska S., Ievdin I., Kovalets I., Trybushnyi D. Software tools and related documentation for the automatic downloading of global meteorological data and operation of the WRF meteorological modelling system, Report NERIS-TP(WP4)-(13)-02. URL: http://dx.doi. org/10.13140/2.1.3572.8002 (Last accessed: 05.05.17).

12. Khalchenkov A.V., Kovalets I.V., Romanenko O.M. Adaptation of WRF meteorological model for forecasting wind fields around the Rivne NPP vokrug Rovenskoy AES na osnove ispolzovaniya modeli WRF. Matematichni mashini ta sistemi (Mathematical Machines and Systems) 2015, 1: 130-138 [in Ukrainian].

13. Kovalets I., Asker C., Khalchenkov A., Persson C., Lavrova $\mathrm{T}$. Atmospheric dispersion of radon around the uranium mill tailings of the former Pridneprovsky Chemical Plant in Ukraine. Journal of Environmental Radioactivity. 2017. 172: 173-190.

14. Steven R. Hanna, Olav R. Hansen, Mathieu Ichard, David Strimaitis, CFD model simulation of dispersion from chlorine railcar releases in industrial and urban areas. Atmospheric Environment. 2009. 43 (2): 262-270.

15. On the territory of flaming oil storage facilities there were 14 thousands tons oil products. - Turchiniov. Ukrainskaya Pravda (9 June 2015). URL: http://www. pravda.com.ua/news/2015/06/9/7070699/ (Last accessed: 05.05.17).

16. Method of computation of release of hazardous matters in atmosphere under free burning of oil and oil products. Samara, Ministry of environment and nature resources Russian Federation. URL: http://meganorm. ru/Data2/1/4293782/4293782525.pdf (Last accessed: 05.05.17).

Received 11.05.17
І.В. Ковалещь, С.Я. Майстренко, О.В. Халченков, Т.О. Загреба, К.В. Хуриилава, С.М. Ануліч, В.П. Беспалов, О.І. Удовенко

Інститут проблем математичних машин та систем НАН України, просп. Глушкова, 42, Киев, 03187, Україна, тел. +38(044)52636 15, ivkov084@gmail.com

ВЕБ-СИСТЕМА «ПОВІТРЯ» ДЛЯ ОПЕРАТИВНОГО ПРОГНОЗУВАННЯ АТМОСФЕРНОГО ЗАБРУДНЕННЯ УКРАЇНИ ВНАСЛІДОК ТЕХНОГЕННИХ АВАРІЙ

У роботі представлено розробку інформаційної технології прогнозування розповсюдження атмосферних забруднень внаслідок аварій з викидами небезпечних речовин, яка базується на інтеграції сценаріїв викидів, моделей атмосферного перенесення різних рівнів складності (від спрощених скринінгових моделей локального масштабу до регіональної моделі CALPUFF) та моделей прогнозування погоди. 3 використанням відкритих ГІСта веб-технологій створено пілотну версію веб-системи «Повітря» для аналізу та прогнозування атмосферного забруднення України, яку було використано для моделювання атмосферного забруднення внаслідок пожежі на нафтобазі у Василькові у червні 2015 р.

Ключові слова: забруднення повітря, веб-система, ГІС, чисельний прогноз погоди, аварія, атмосферна дисперсія, Васильків, пожежа, нафтобаза.

\section{И.В. Ковалец, С.Я. Майстренко, А.В. Халченков, Т.А. Загреба, К.В. Хуриилава, С.Н. Анулич, В.П. Беспалов, О.И. Удовенко}

Институт проблем математических машин и систем НАН Украины, просп. Глушкова, 42, Киев, 03187, Украина, тел. +38(044)526 36 15, ivkov084@gmail.com

\section{ВЕБ-СИСТЕМА «ПОВІТРЯ»}

ДЛЯ ОПЕРАТИВНОГО ПРОГНОЗИРОВАНИЯ

АТМОСФЕРНОГО ЗАГРЯЗНЕНИЯ УКРАИНЫ

ВСЛЕДСТВИЕ ТЕХНОГЕННЫХ АВАРИЙ

В работе представлено разработку информационной технологии прогнозирования атмосферного распространения загрязнений в результате аварий с выбросами опасных веществ, основанной на интеграции сценариев выбросов, моделей атмосферного переноса различных уровней сложности (от упрощенных скрининговых моделей локального масштаба до региональной модели CALPUFF) и моделей прогнозирования погоды. С использованием открытых ГИС- и веб-технологий создано пилотную версию веб-системы «Повітря» для анализа и прогнозирования атмосферного загрязнения Украины, которая была использована для моделирования атмосферного загрязнения в результате пожара на нефтебазе в Василькове в июне 2015 г.

Ключевые слова: загрязнение воздуха, веб-система, ГИС, численный прогноз погоды, авария, атмосферная дисперсия, Васильков, пожар, нефтебаза. 